\section{A poisonous present}

Kampfstoff-Forschungim

National sozialismus: Zur Kooperation

von Kaiser-Wilhelm-Instituten, Militär

und Industrie. [Weapons Research in

National Socialism]

by Florian Schmaltz

Wallstein: 2005.676pp. €39

\section{Benno Müller-Hill}

Germany started developing chemical weapons nearly a century ago, during the First World War. Fritz Haber, then director of the Kaiser Wilhelm Institute of Physical Chemistry in Berlin, collaborated with the chemical industry and the army to set up Germany's powerful industrial-military complex (see Nature 438, $158-159 ; 2005$ ). After the war, research on chemical weapons in the Weimar Republic was forbidden by the Allies, but it was still done secretly on a small scale. In KampfstoffForschung im Nationalsozialismus, Florian Schmaltz tells how this research re-emerged under the Nazis between 1933 and 1945.

When Hitler came to power in January 1933, Germany no longer had a centre for research on chemical warfare. Haber was still director of the Kaiser Wilhelm Institute but he was told that his group leaders must be fired because they were Jewish. Haber, who was also Jewish, decided to go too, leaving the institute in ruins. Three young chemists from Göttingen, all members of the Nazi party, were sent to Berlin to take over.

Gerhart Jander, an inorganic chemist, had friends in the SA (the stormtroopers) and was forced to leave after the Rohm putsch, when Hitler purged the SA. Rudolf Mentzel, an inexperienced chemist, had no interest in doing research himself and became a science administrator in the Reichsforschungsrat, a German funding agency. In 1935, Peter Adolf Thiessen, a physical chemist, became the institute's director. The research focused on an explosive known as N-Stoff (chlorine trifluoride), which Thiessen hoped would prove more destructive than nitroglycerol. Despite being produced in large amounts, it was never successfully used. After the war, Thiessen made a career as a research administrator in East Germany, although Schmaltz does not discuss that here. He does, however, discuss five other Kaiser Wilhelm institutes that worked on gas warfare. Most were occupied with perfecting gas masks, clothing and shoes as protection against weapons such as mustard gas.

The most disquieting part of the book is the story of Richard Kuhn, who won a Nobel prize in 1938 for his work on carotenoids and vitamins. One-third of his lab at the Kaiser Wilhelm Institute for Medical Research in Heidelberg was occupied with research on poisons that could be used as weapons. When his colleague Otto Meyerhof left the institute in 1938, Kuhn took over some of his lab space. This gave him access to the nerve poisons tabun and sarin, synthesized in secret in 1936 and 1939 by chemists of the IG Farben companies. The Allies only learned of their existence shortly before the end of the war. Kuhn's colleagues showed that the poisons worked by inhibiting acetylcholine esterase, and his laboratory synthesized an even more effective acetylcholine esterase inhibitor, soman, in 1944. These poisons were synthesized in large quantities for use in grenades, but they were never used. One reason is that it was impossible to protect German soldiers and civilians from the poisons. According to Schmaltz, "these poisons were a present for the future".

Kuhn was also a great science administrator. As a member of the Reichsforschungsrat, he chose to finance the mustard-gas experiments of his colleague Otto Bickenbach, who proposed to test vitamin $B_{6}$ as a possible protective agent against the gas. For his experiment, he mainly used gypsies from the concentration camp of Natzweiler-Struthof, four of whom died. Bickenbach was later condemned by a French court to 20 years in jail. During the lawsuit, Kuhn wrote to Bickenbach's lawyer, saying that the experiments were "scientifically perfect" and "a blessing for future generations". Bickenbach was released in 1955 after a German medical court found nothing wrong with his experiments and allowed him to practice medicine again.

Schmaltz, a historian, presents all this and much more in great detail. The flow of money between industry, the army and science, in particular, is well documented, but the chemistry is flawed in places. The structures of sarin and soman are given, but that of tabun is missing, and the structure of pinacoline alcohol, a precursor of soman, lacks an $\mathrm{OH}$ group. In addition, not everything presented in the book is new. And the author also acknowledges that some documents may have been destroyed or lost in Russia, so the story is not complete.

The book should appeal to all those interested in chemical warfare or in the history of the Kaiser Wilhelm institutes — but it may be too detailed for the general reader.

Benno Maller-Hill is professor emeritus at the

Genetics Institute, University of Cologne,

Cologne 5064, Germany.

\title{
The latest on latex
}

\section{Tears of the Tree: The Story of Rubber- A Modern Marvel \\ by John Loadman \\ Oxford University Press: 2005. 336 pp.}

£19.99, \$37.50

\section{Robert W. Cahn}

In 1770 , an artists' supply shop in London offered for sale half-inch cubes of a mysterious material that was called 'rubber' because it could be used to rub out pencil marks. The price was 3 shillings per cube, a large sum at the time - but then, nothing else was as effective in correcting artists' mistakes.

This is one of many pieces of information offered in John Loadman's miscellany of a book, Tears of the Tree. The book's purpose, he announces at the outset, is "to examine the story of natural rubber in its social context". In fact, about half the book is devoted to the social context, and this is its main merit.

The story of rubber begins with its discovery and use by Meso-American civilizations in what are now Guatemala and Mexico. In particular, rubber balls were used for formal competitive games; the losers were usually killed, their heads cut off and coated with latex from the rubber tree to make the next (properly weighted) balls. But the most horrendous stories in the book are about the 'rubber barons' in the western extremes of Amazonia, and the exploitation by Belgian King Leopold II of the natives of the Congo in the late nineteenth century. The social context of primary rubber production was uniformly depressing until 1877 when, after numerous abortive attempts, seeds of the wild rubber tree were at last successfully (if unofficially) transferred from Brazil to the Royal Botanic Gardens at Kew, near London. They were then germinated and transferred to the Far East, Malaya in particular, establishing a major primary industry.

The exploitation of rubber provided extensive benefits for developing industrial societies. The story - especially the slow, faltering steps to find the best way to harden raw rubber by vulcanization - is told in interesting detail. Patents play a major role in this tale, and the biographies of the principal players are excellently presented. The cycle is completed with a critical survey of attempts to recycle waste rubber.

The book then changes gear and focuses on the production technology of vul canized variants of rubber, both natural and synthetic. The treatment becomes extremely technical in terms of the organic chemistry of different kinds of polymeric molecules, and even more so when the minutiae of the chemical deterioration of rubber are set out. At this point, in my view, the book begins to stutter.

The science and technology of polymers in general, and of elastomers in particular, has three essential constituents: physics, chemistry and production technology. With a background in chemistry and long experience in a 
IMAGE

\section{UNAVAILABLE FOR COPYRIGHT REASONS}

Tapping into nature: the production of tyres and medical gloves starts here, at the rubber tree.

research institute focused on natural rubber, Loadman knows about chemistry and production technology, and his presentation of the chemical aspects is technically detailed. But explaining the chemistry is not enough.

The problem comes with the physics. Load- man claims that the physical theory of 'rubberlike elasticity' is too involved to present in any detail, so the source of rubber's elastic restoring force and of the very large elastic strains that can be attained is left unexplained. The elastic behaviour of rubber is fundamentally different from that of other, non-polymeric, solids: it is entropy made tangible, and no explanation is adequate unless it takes into account the probabilities of different microstructural arrangements of the polymer chains.

One difficulty in the book is the author's use of the word 'elastic.' He uses it to denote the capacity to generate very large reversible strains - that hasn't been the sole meaning since Hooke's work on elasticity in the seventeenth century. Furthermore, rubber, especially before it has been vulcanized, is not elastic but viscoelastic the strain generated by an applied force varies with time under stress. This characteristic governs many features of rubber, including the adhesion of a tyre to the road surface and the comfort of someone sleeping on an elastomeric mattress.

The book is full of interesting information. But it is uneven, and the gear changes are so abrupt that the narrative tyre tends to skid. Robert W. Cahnis in the Department of Materials Science and Metallurgy, University of Cambridge, Pembroke Street, Cambridge CB2 3QZ, UK.

\section{INSTALLATION}

\section{Uranium days}

The Children of Uranium

At the Museo d'Arte Contemporanea di Villa

Croce, Genoa, Italy, until 18 December.

In Eng lish. www.museovillacroce.it

\section{Sylvie Coyaud}

Peter Greenaway is best known as a filmmaker. But he actually trained as a painter, and his particular sense of aesthetics is exhilaratingly apparent in his new multimedia operacum-installation, The Children of Uranium, which opened during the Genoa Science Festival earlier this month.

Created together with theatre director Saskia Boddeke, the work explores Greenaway's longstanding concern with the history of the element uranium. It is played out in a nineteenth-century palazzo, now used as an art museum. The palazzo's first floor and the grandiose staircase leading to it were cleared and redecorated for the installation. Each of the eight rooms is home to a different protagonist - from Marie Curie to George W. Bush - all of whom have played some role in society's

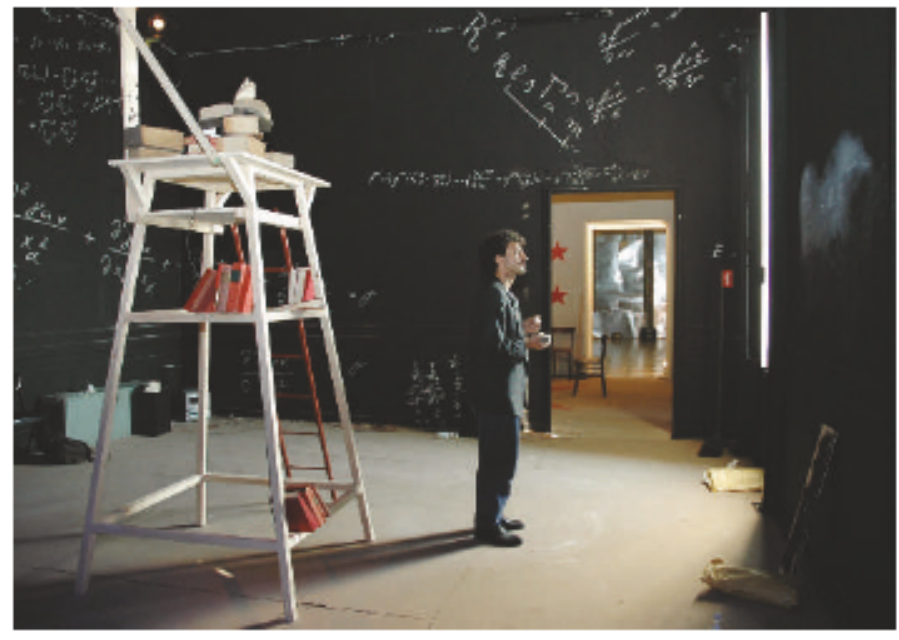

Albert Einstein makes the case for the bomb in The Children of Uranium. he shares, in dance, an apple, which is suspended by an invisible thread from the ceiling. The music rises and a tenor climbs the staircase singing, in a slightly threatening chant, the names of the first 92 elements of Mendeleev's periodic table. Despite his eighteenth-century court costume, this is the angel Moroni, who led the founder of the Mormon Church, Joseph Smith, to Utah and to the uranium mines of Moab. Upstairs he becomes Smith and ushers the audience into a room made up as the Oval Office, where President Bush plays with pencils, mulls over how to destroy the axis of evil, gets bored and practises his golf shots.

Meanwhile, in another room, Marie Curie kneels on pitchblende pebbles, surrounded by cabinets of laboratory glassware, and talks to her dead husband. "What have I obtained, what have I lost?" she cries over and over again. Butterflies seem to fly out from the pattern of the wallpaper to follow her in a dim beam of light, in a scene reminiscent of Gabriel García Márquez's A Hundred Years of Solitude, vanishing as she enters Robert Oppenheimer's grey cave. Here Oppenheimer watches, in anguished silence, the first nuclear explosion, projected in a continuous reel on to a finemeshed screen, as if on smoke. He clutches to his chest a framed picture of a deformed baby.

Next door, Albert Einstein writes, smokes a pipe and chats with other performers in a study cluttered with books and papers, blackboards and equations. His letter of August 1939 to Franklin D. Roosevelt, in which he urges the president to build an atomic bomb before the Nazis do, is projected on the floor.

In a prison cell, Nikita Khrushchev reenacts his speech at the United Nations during the Cuban missile crisis, while the speech is shown on a television set. Mikhail Gorbachev mourns his wife, Raisa, next to her coffin. Her dresses hang listless from the ceiling, from which water starts to leak.

"Political decisions should not be left to scientists, sing the tenor and the soprano. Were they ever? But, the opera seems to tell us, perhaps they should also not be left to the bored US president, nor to Khrushchev, drunk on vodka and the power of his nuclear weapons, nor yet to Gorbachev, a loser, broken by the death of his wife and the fall of the Soviet Union. "We are all the children of uranium," the singers continue. How we use it is for us, the people, to decide.

The live performance comes to an end, but recordings have been intelligently incorporated into the installation. Its large scale and small details challenge and perplex. Greenaway's relationship with physics remains ambiguous, but his creation is visually stunning. Sylvie Coyaud is a science journalist based in Milan, Italy. 